\title{
Validation of the Parenting Stress Index (PSI) among mothers of Preschool children in Tehran
}

\author{
Hamed Babakri ${ }^{1}, \underline{\text { Siamak Tahmasebi }}^{2}$, Shahin Amani ${ }^{3}$ \\ 1- Masters student pre-school education, University of Rehabilitation Sciences and Social Welfare, Tehran, Iran. \\ ORCID: 0000-0003-4801-6055 \\ 2-PhD in Clinical Psychology University of Rehabilitation Sciences and Social Welfare, Tehran, Iran. ORCID: \\ 0000-0003-2005-8800Ｅ-mail: siyamak.tahmasebi@gmail.com \\ 3-Masters student pre-school education, University of Rehabilitation Sciences and Social Welfare, Tehran, Iran. \\ ORCID: 0000-0003-0121-0459
}

Received: 17/06/2018

Accepted: 21/10/2018

\begin{abstract}
Introduction: Due to the influences of family instability in creation and development of behavioral and emotional disorder in children, researchers have urged to study stress as a significant factor in this field.
\end{abstract}

Aim: The present study was Validation of the Parenting Stress Index (PSI) among mothers of preschool children in Tehran.

Method: The study was a descriptive and correlation. The statistical population was the parents of children aged 4-6 years old in Tehran and 378 of them were selected. To determine the validity of this index, the CBCL questionnaire and the Blum Quist Growth Scale used. Software was used to analyze the data SPSS

Result: The reliability coefficient for Stress Index was $89 \%$ and correlation coefficient between parenting stress scale with CBCL questionnaire and Bloom quist's questionnaires was $23 \%, 68 \%$, respectively. All Correlation coefficients were significant at the 0.01 level

Conclusion: Parenting stress index could be used as a reliable tool for the age of 4-6 in clinical and non-clinical studies.

Keywords: Parental Stress, Emotional and Behavioral Disorders, Adaptation

How to cite this article : Babakri H, Tahmasebi S, Amani Sh. Validation of the Parenting Stress Index (PSI) among mothers of Preschool children in Tehran. Shenakht Journal of Psychology and Psychiatry. 2018; 5 (4): 29-39 .URL :http://shenakht.muk.ac.ir/article-1-405-fa.pdf

Copyright (C) 2018 the Author (s). Published by Kurdistan University of Medical Sciences. This is an open access article distributed under the terms of the Creative Commons Attribution-Non Commercial License 4.0 (CCBY-NC), where it is permissible to download, share, remix, transform, and buildup the work provided it is properly cited. The work cannot be used commercially without permission from the journal. 


\title{
انطباق و هنجاريابى شاخص تنيدكى والدين (PSI) بر روى مادران كودكان تهرانى
}

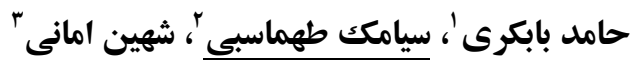

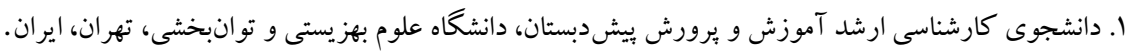

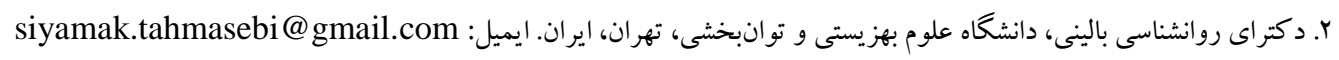

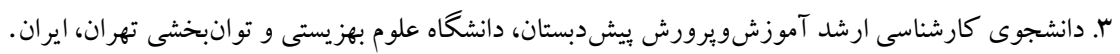

مقدمه: تأثير نابسامانىهاى خانوادگى در ايجاد اختلالهاى رفتارى و عاطفى كود كان، يزّوهشخران را به مطالعهى تنيدگى بهعنوان

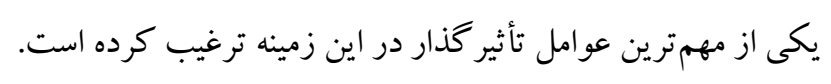
هدف: اين مطالعه با هدف انطباق و هنجاريابى شاخص تنيدگى والدين (PSI) بر روى مادران كود كان تهرانى انجام گرديد.

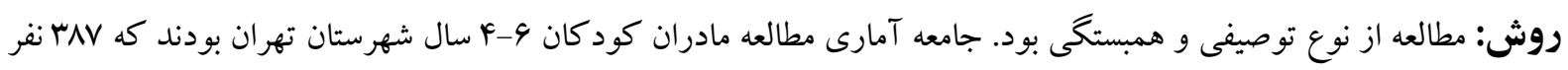

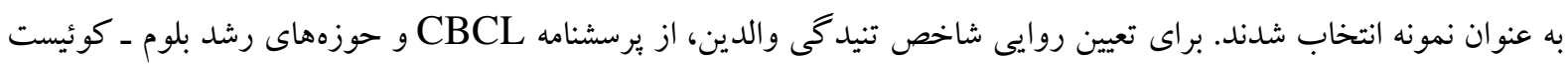

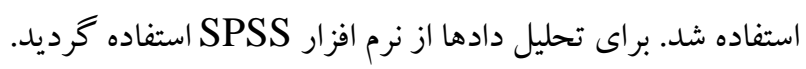

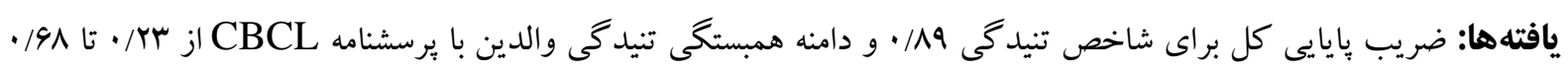
محاسبه و همه ضرايب در سطح 1 • • معنى دار بودند.

نتيجه كيرى: شاخص تنيدگى والدين مى تواند بهعنوان يكك ابزار معتبر در تحقيقات بالينى و غير بالينى براى مقطع سنى \& الى 4 سال مورداستفاده قرار گيرد. كليدوازه: تنيدگى والدين، اختلالات عاطفى و رفتارى، انطباق 


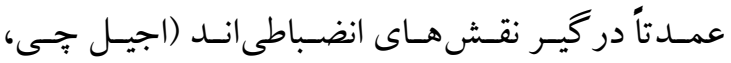

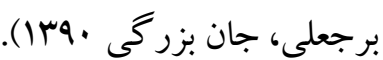
تنيدگى والدينى' اصطلاحى است كه مشخص كنئده ادراكك تنيدگى در نظام والد- كودكى است كه هم

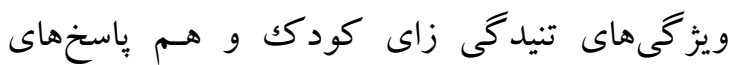

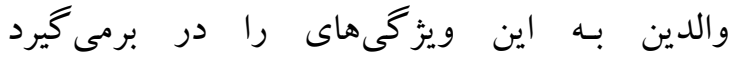

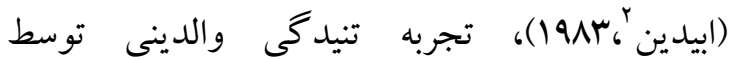

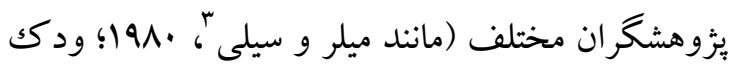

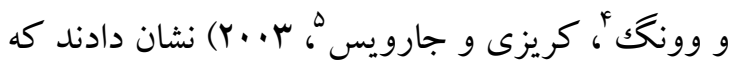
والدگرى براى هر دو والد تنيدگى زاست، اما مادران بيش از يدران تنيدگى والدينى را تجربه مى كنند.

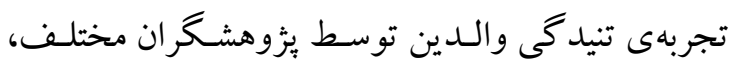

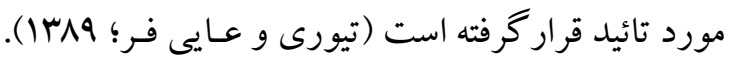

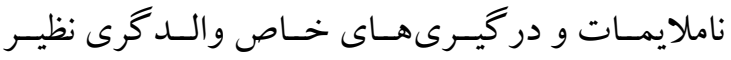
مديريت هيجانهاى كودك (دادستان، احمدى ازغندى و حسن آبادى.هNم|) و مشكلات روزمره مانند تغذيه و خواب يا گريه بيشازحسل و عفونـتهـا و بيمـارىهـاى كودك (دادسـتان، احمـدى ازغنـدى و حسـن آبـادى. همب1()، منجر به تجربهى تنيدگى والدينى مى شود.

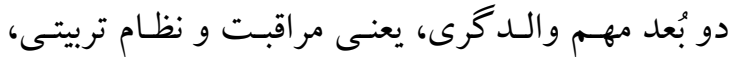

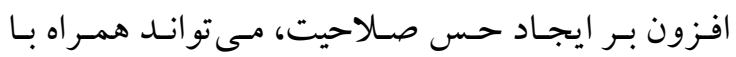
دشوارىهاى ناشى از اين مسئوليت بـه احسـاس فشـار و تنيدگى در والدين منجر شوند كـه ايـن تنيـدكى هــا نيـز بهنوبه خود، كاهش توانايى والدين در شناسايى و درك صـحيح بيـامهـاى كــودك و در نتيجـهـ نـاتوانى در ياسـخگ

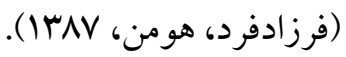
با توجه به نقش تنيدگى در زندگى روزمره هوره و اثرات

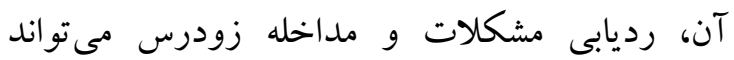

1 Parenting Stress
مقدمه تولد يك كودكك، علىرغم شادى و سرورى كه همراه خـود بـه كـانون خـانو اده مسى آورد، باعـث بديدارشـان مسئوليتهاى جديد بــاى والـدين خواهــ شـــ. ظهـور

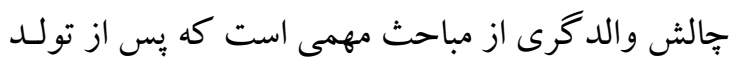

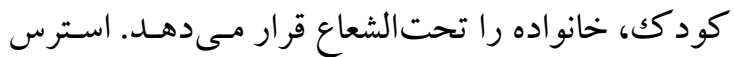

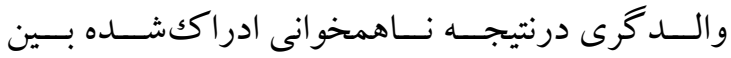
تقاضـاهاى والـدين و منــابع فــدى حاصـل مسى شــود

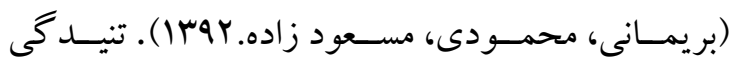

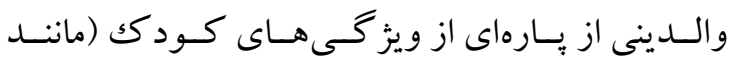

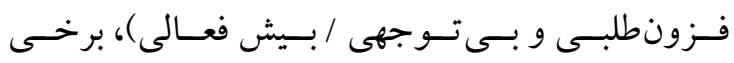
خصيصه هاى والدين (افسردگى و حس صلاحيت) و يـا موقعيتهاى متنوعى كه با ايفاى نقش والـدينى بـهور مستقيم مـرتبط هستند (مانتـد روابـط همسـر و سـلامت

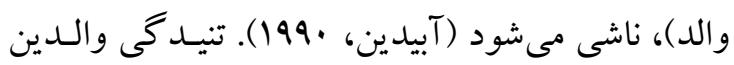
درواقـع اصـطلاحى اسـت كـه مشـخص كنـــده ادراكى تنيدگى در نظام والد-كودكى است كه هم ويز گیى اصناى

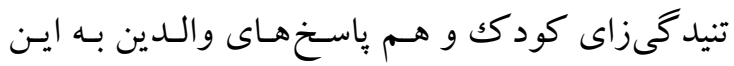

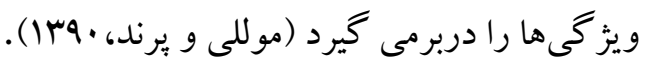
تحول در كود كان خردسـال بـه علـت كـنشورى هـاى يويايى تحولى در اوان كودكى (تولد تـا هفـت سـالكى) توجه و نظارت دقيق ترى را از طـرف مـادران مسىطلبـ

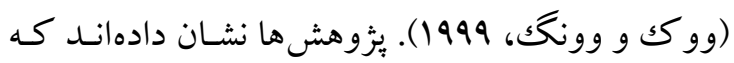

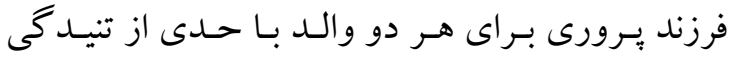

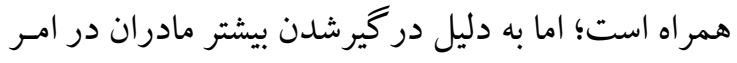
مراقبت از كودكك، بـه خصوص در دوره بـيش دبسـتانى

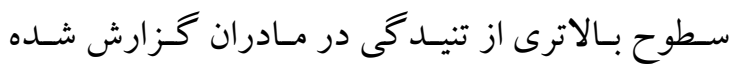
است. مادران در جو امع شـرقى نقـش مراقبـت گكرى در قبال نيازهاى جسمانى، عـاطفى و اجتماعى كودكان را

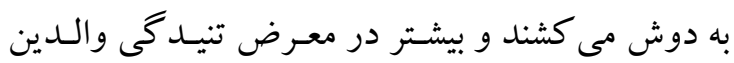

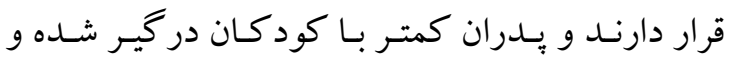


والدين باعـث مسىشـود كـه آنهـا گـرايش بيشترى بـهـ

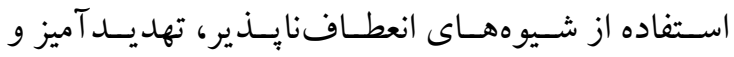
يرخاشگرانه والدگرى داشته باشند و كمتر از برنامههاى

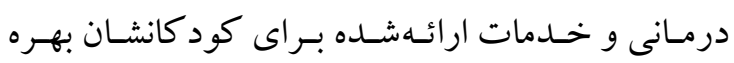
ببرند؛ و از اينرو در تصميم گيرى دربـاره مناسـبتـرين

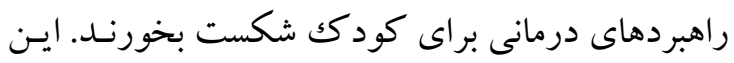

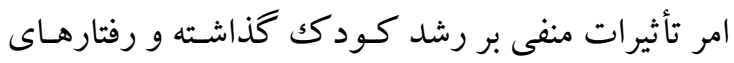

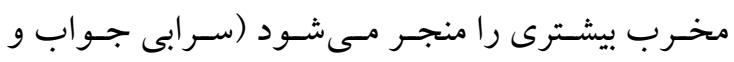

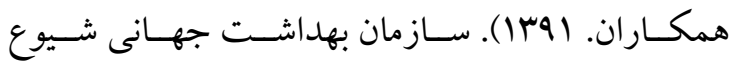
مشـكلات روانسى در بــين كود كـان ب تـا هـ سـاله در

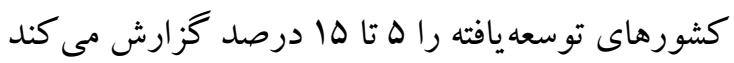

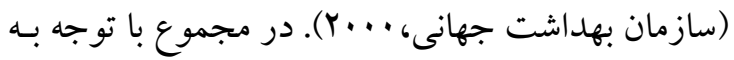
آمـار و ارقـام ارائسهــــه درزمينـهى افـزايش كودكـان مبتلابه مشكلات رفتـارى و ايـن حقيقـت كـه مشكلات رفتارى تمام جنبههـاى زنـدكى فردى و اجتمـاعى ايـن

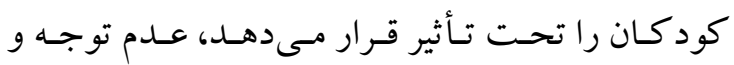
رسيدكى به اين مسئله مى تواند به شيوع بيشـتر و مـزمن شدن اختلالات آنها منجر شود.

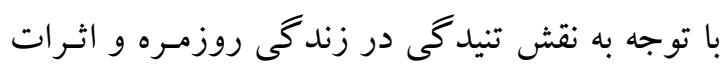

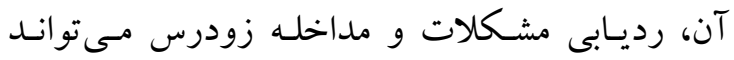
فراوانى و شدت اختلالهاى رفتارى و عاطفى كود كان را در جامعه كنونى كاهش دهد و روشى كه بتوان بر اساس آن جخونخى روابط والد-كودكى را در شرايط

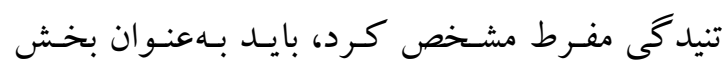

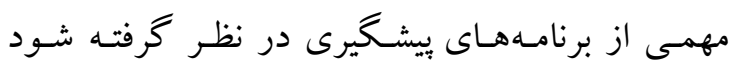
(فرزاد و همكاران؛ سیז|).

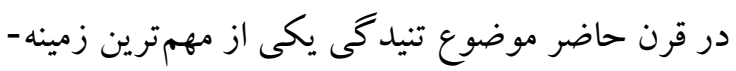
هاى بثزوهشى در علوم مختلف بوده است. اين موضوع توجه دانشمندان رشتهاى مختلف اعم از يزشكان،

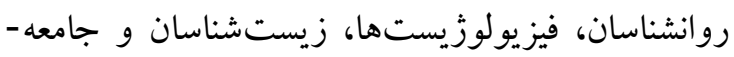
شناسـان را به خود جلب كرده و هر كدام جنبه هايى از مسائل مربوط به تنيدگى را موردبررسى قرار دادهاند.
فراوانى و عاطفى كود كان را در جامعه كنونى كاهش دهـد و روشى كه بتوان بر اساس آن شدت اختلالهاى

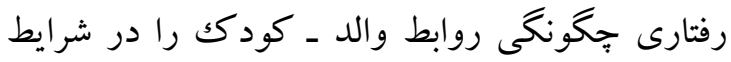

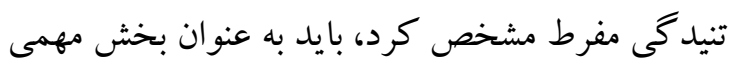

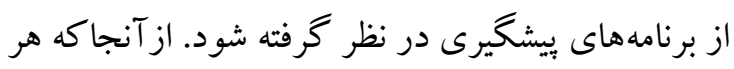
جه طول مدت مشكلات فرد بيشتر باشد درمان آن مشكل تر مىشود (سيف، IrNV

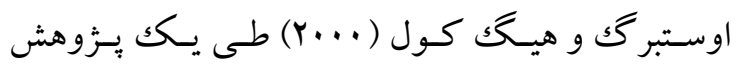
كسترده نتيجه گر فنتد كه شناخت كود كك بهعنو ان يـك

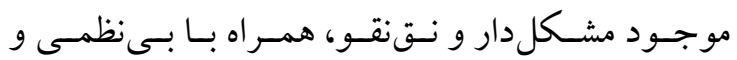

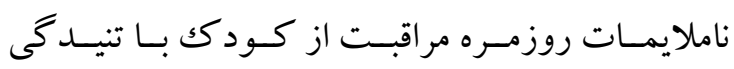

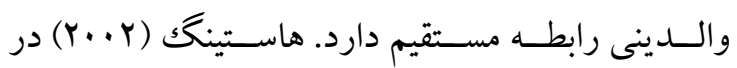

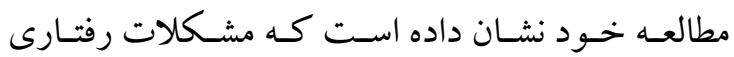
كود كك تنيـدگى والـدين را، حتى هنگَـامى كه منزلـت اقتصادى-اجتماعى خانو اده و حمايت اجتماعى والـدين كنترل مىشود، ييش بينى مى كنند (شهركى يسور، كريم زاده، كرامتى؛

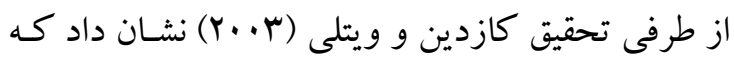

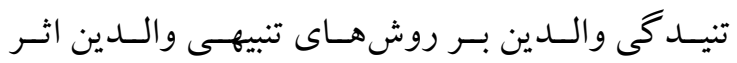

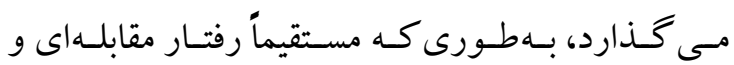

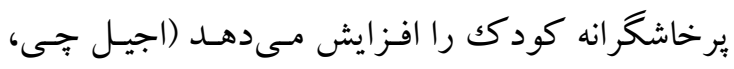

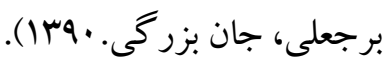

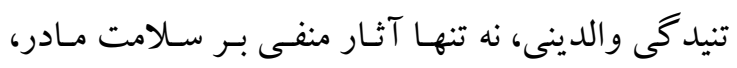
بلكه تأثيرات مخربى بر كودك مسى گحذارد (تيمسورى و

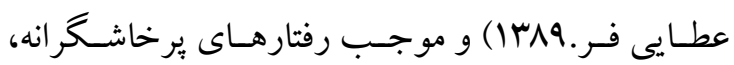
نافرمانى، اختلال سـلو كك و رفتارهـاى ضـداجتماعى در كود كـان مسىشـود. اسـترس والـــين موجــب افـزايش رفتارهـاى نامناسـب كـود كك شــده و رفتـار نامناسـب مونب كودكك متقابلاً به بالارفنن استرس والدين منجر مىشود

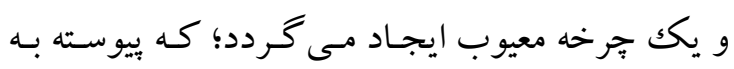
تعامل والد- كودك آسيب مىرسـاند (شكوهى يكتـا،

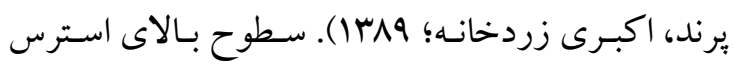


كه با روش نمونه گيرى طبقـهاى انتخـاب شـدند، انجـام شد. براى گرد آورى اطلاعات از دو برسشنامه بـه شـرح

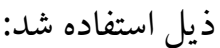

مقياس رشل كودك (بلوم كويست،و. • +ץ): كـه شـامل

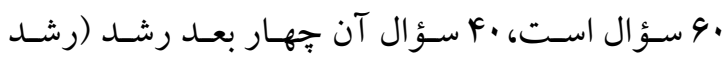
هيجانى، اجتماعى، خود كنترلى و رشـد تحصيلى) و r. سؤال باقيمانده بهزيستى والدين و روابـط خـانوادگى را مىسنجد. فهرسـت رفتـارى كودكسان (CBCL): كـه در نظـام سنجش مبتنى بر تجربه آخنبـاخ بـراى ارزيـابى سـنجش

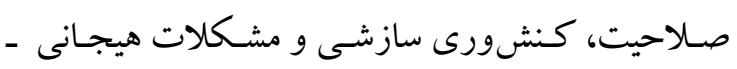
رفتارى كود كان معرفىشده است. اين فهرسـت، توسط والدين يا فردى كه سريرستى كودك را بـر عهـده دارد

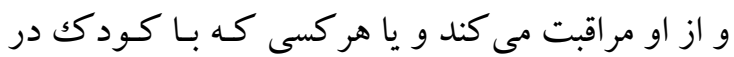

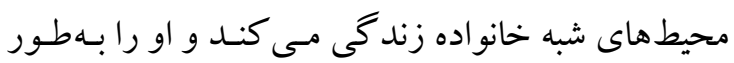
كامل مى شناسد، بر اسـاس وضعيت كود كك در 9 مـاه

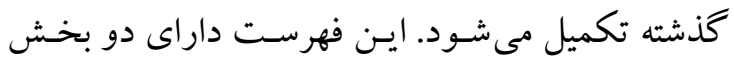

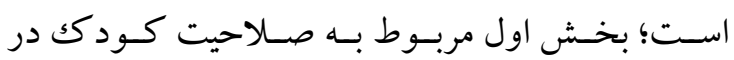
زمينه هاى مختلف نظيـر فعاليـتهـا، روابـط اجتمـاعى و مدرسه است و بخش دوم مربوط به مشكلات هيجـانى -

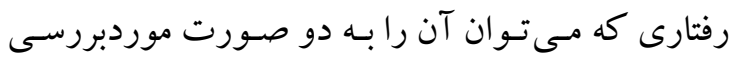

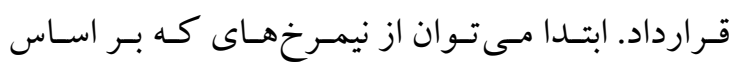
اختلالهاى DSM_IV تنظيم شده است، استفاده كرد. اين جهت گيرى بر اسـاس DSM، مشـكلات هيجـانى،

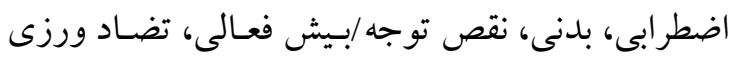

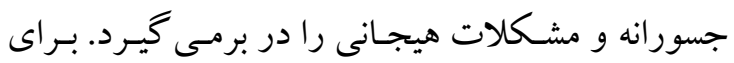
تشـخيص نشـانگان در فهرســت رفتـارى كــودك از روشهاى تحليل عوامل استفادهشده است كه بر اسـاس

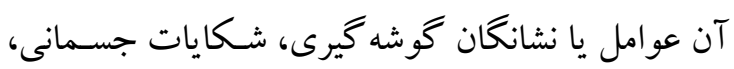
اضـطراب/افسـردگىى، مشـكلات اجتمـاعى، مشـكلات

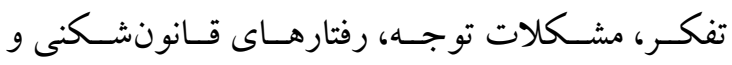

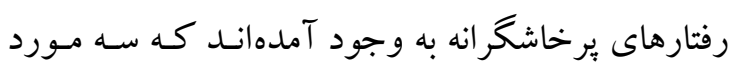

انسانها در سراسر تاريخ تنيدگى را تجربه كردهاند، امـا در طى اين قرن مسكلات ناشى از آن، بهخصوص در كشورهاى صنعتى و ييشرفته افزايش يافته است، به طورى كه تنيدگى بيمارى جديد تمدن نام گرفته است (ابيدين، · • (199). بنابراين، تشخيص مشكلات تنيدكى والدين (والدگرى) از اهميت بيشترى برخوردار است و ابزارى كه امكان بازشناسى زودرس جنين موقعيتهاى مخاطرهآميزى را

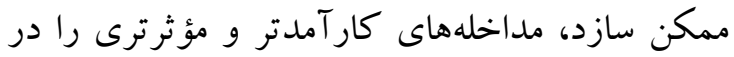
يى خواهد داشت. آزمون تنيدگى والدينى (والدگرى) يرسشنامهاى است كه مىتوان با استفاده از آن ميزان

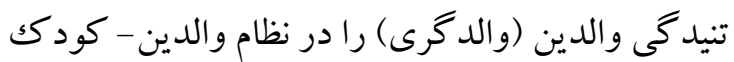
ارزيابى كرد (فرزاد،MM||) همجينين با توجه به اينكه تحقيقات، فوايد بلندمدت شناسايى و تشخيص

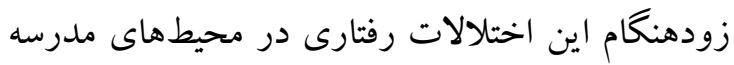
را نشان دادهاند؛ اما بزوهشهاى محدودى در مورد شيوع آسيبشناسى روانى و اختلالات رفتارى در كودكان كمتر از 9 سال وجود دارد و بيشتر مطالعات روسي صورت بذيرفته در مورد سنين بالاتر بوده است. بنابراين با توجه به عدم وجـود شـاخص هنجارشـده در

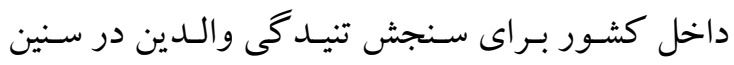

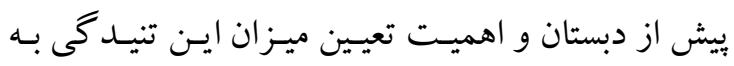

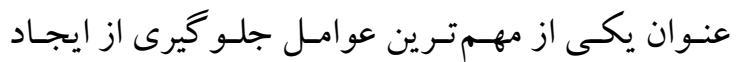
ييامسدهاى منفـى آن در كودكــان يـيش از دبســان و همجنين استفاده از آن در درمانها و امور بالينى و غيره،

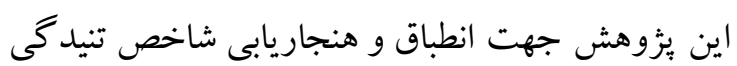
والدين (PSI) بر روى مـادران كودكـان تهرانسى انجام كرفت.

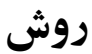
مطالعـه حاضـر بـه روش توصسيفى - همبسـتخى بـر روى رون

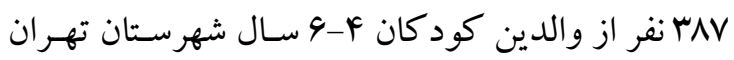




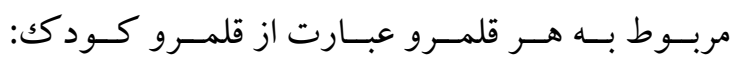

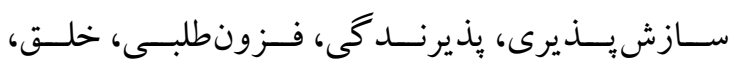
بى توجهى/فزون كنشى، تقويت گَرى؛ قلمـرو والـدين:

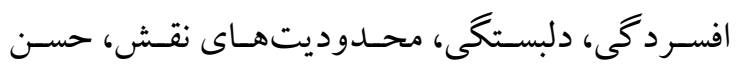

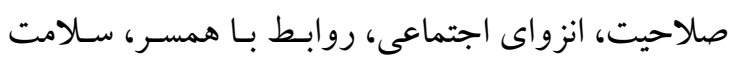

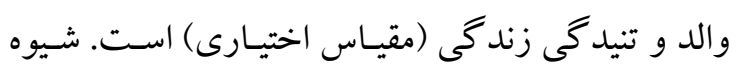

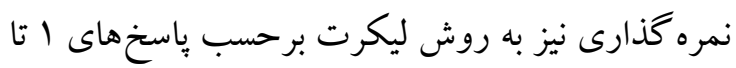

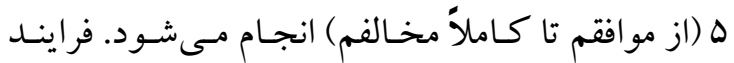
تفسير نتايج مقياس تنيدگى والدينى، در وهله نخسـت از ماز بررسى نمره كلى مقياس (قلمروهاى كودكك و والدين)

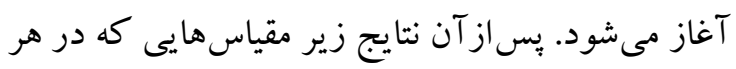
قلمرو قرار دارند بر اساس جدول نرم، مورد تحليل قرار

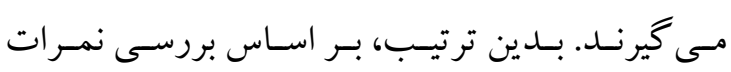

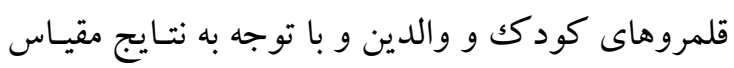
تنيدگى زندگى، مى توان جارجّوب خاص بروز تنيدگى

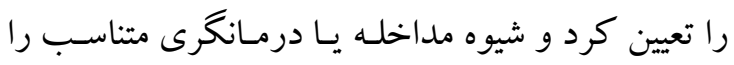
اتخاذ نمود.

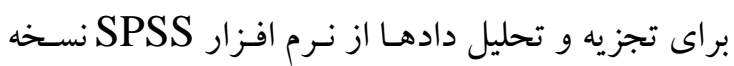
•r و بـا آزمـونهـاى آمـارى آزمـون آلفـاى كرونبـاخ،

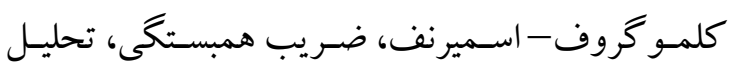
واريانس و تحليل عاملى استفاده گرديد.

\section{يافتهها}

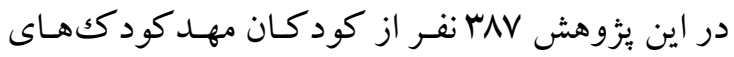

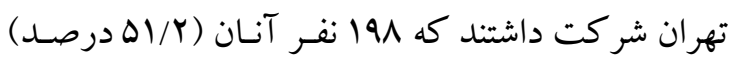

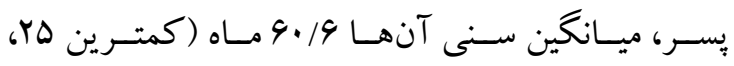

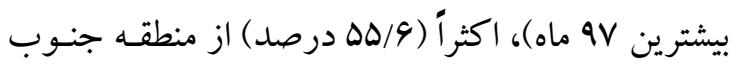
تهران و مهد كودك ب Y بهمن (90 نفر ) بودنـد. ميـانكين

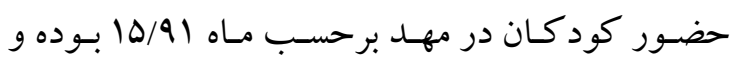
كود كان اين مطالعه روزانه به مدت حدود 4 سـاعت در مر برد مهد مى ماندند. ا9 درصـد از خروه نمونـه تـك فرزنـد،

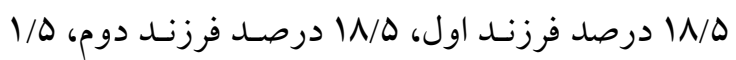

نخست، تشكيل دهنـده مشككلات درونسو و دو مـورد انتهايى تشكيل دهنده مشكلات برونسو هستند. مىتسوان

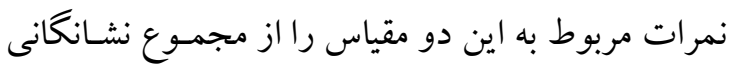
كـه در ايسن مقيـاس قـرار مسى گيرنسـ، بـه دسـت آورد.

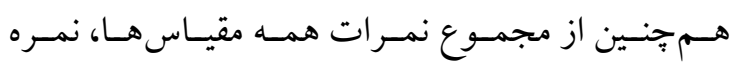
مشكلات كلى به دست مى آيد.

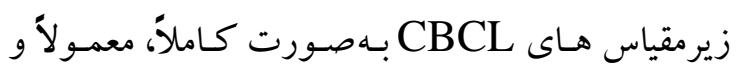

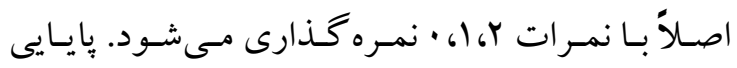

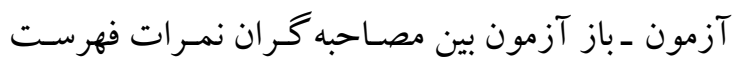

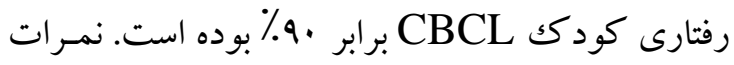
بين Y CBCL اين نظـام در شهرسـان تهـران بـر روى كودكـان مقطع

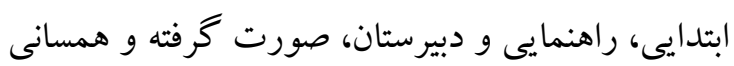
درونى اين نظام در مشكلات رفتارى هيجـانى كودكـان رضايتبخش بوده است. همجنين در اعتبار آزمون -باز آزمون تمام همبستكى هـاى گثـتاورى بيرسـان معنسادار

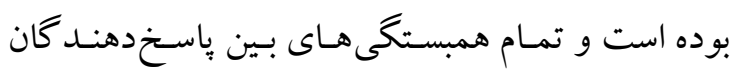
شامل توافق بين والدين، معلمان و كود كان معنادار بوده

شاخص تنيدكى والدين (PSI): توسط آبيدين ( • (199) ساخته شده است و يرسشنامهاى است كـه بـر اسـاس آن

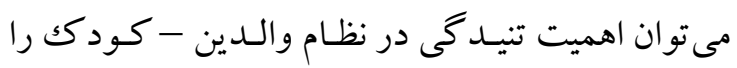
ارزشيابى كرد. ايـن يرسشـنامه بـر ايـن اصـل اسـت كـهـ

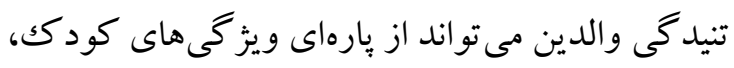

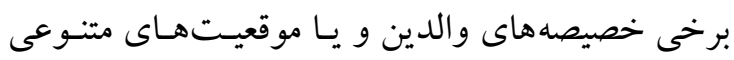
كه با ايفاى نقش والدينى بهطور مستقيم مـرتبط هسـتند، ناشى شود. شكل شاخص تنيدگى والدين اين يـرٔوهش، بهعنوان شكل بازنكرى شده شكل هاى بيشين اسـت كـه تصحيح آن آسانتر و مقدار مواد آن كمتـر اسـت. ايسن

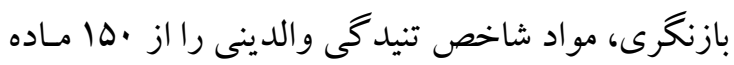

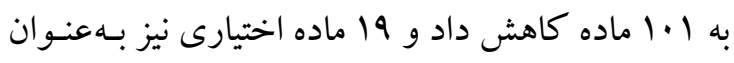
(مقياس تنيدگى زندگىى" به آن افزود. زيـر مقيـاسهـاى 
كـرى

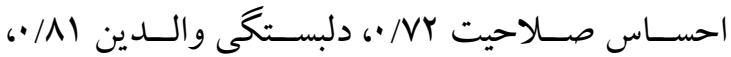

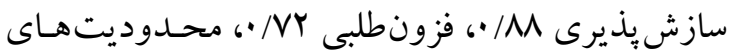

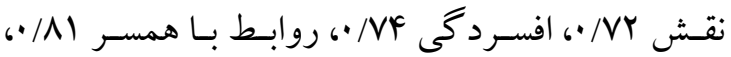
انزواى اجتماعى AF/ •، سلامت والدين سN/ •، اختيـارى

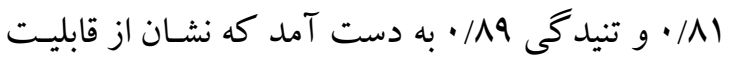
اطمينان برسشنامه دارد. براى بررسى طبيعى بـودن داده هـا و متغيرهـا از آزمـون كلمو گروف - اسميرنف استفاده شـد كـه نتـايج آن در جدول شماره ا آورده شده است.
درصد سـوم و ه/ • درصـد فرزنـد جهارم بودنــ. درصد از مـادران تحصسيلات ليسـانس، \&/Y درصــ از

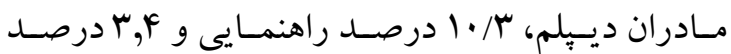

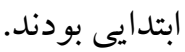
براى بررسى ضرايب همسانى درونى از آلفاى كرونبـاخ استفاده شد. ضـرايب همسـانى درونسى آلفـاى كرونبـاخ

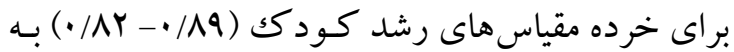
دست آمد، همجنين نتايج آزمون يايايى آلفاى كرونباخ براى متغيرهاى اندازه گيرى شده در يرسشنامه شـاخص تنيدگى والدين (بى توجهى /فزون كنشى ·V/ •، تقويـت

\section{جدول ا: يافته هاى توصيفى متغيرهاى تنيدكى والدين و رشد كودكى و ابعاد آنها}

\begin{tabular}{|c|c|c|c|c|c|c|c|}
\hline Sig & $\mathbf{Z}$ & انحر اف معيار & ميانگين & بيشينه & كمينه & تعداد سؤال & متغير \\
\hline$\cdot / Y \Lambda$ & $\cdot / 9 r$ & $\Delta / \Gamma$ & $r \varepsilon / F$ & rq & $1 \Lambda$ & 9 & بى تو جهى/فزون كنشى \\
\hline 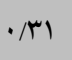 & .190 & $r / f$ & $M / F$ & $r$. & $\wedge$ & 4 & تقويت گرى \\
\hline$\cdot / r$ & .194 & $r / 1$ & $19 / 9$ & ro & 9 & $\Delta$ & خلق كودك \\
\hline$\cdot 119$ & $\cdot|+|$ & $\Delta / 1$ & $r \Delta / q$ & ro & ir & $\checkmark$ & يذيرند \\
\hline$\cdot / r t$ & $.19 \mathrm{~V}$ & $9 / 9$ & $r V / r$ & $\Delta F$ & 11 & ir & احساس صلاحيت \\
\hline$\cdot 119$ & $\cdot / 19$ & $r / r$ & $r Y / r$ & ro & 19 & $\checkmark$ & دلبستخى والدين \\
\hline • & .194 & $9 / 0$ & $r Y / 9$ & $\Delta r$ & $r \cdot$ & 11 & سازش بِذيرى \\
\hline$\cdot / \mu r$ & $\cdot / 94$ & $F / \Lambda$ & rQ/9 & Fi & ir & 9 & فزون طلبى \\
\hline$\cdot / 1$ & $1 / \cdot 9$ & $\Delta / \Delta$ & rr & ro & If & $\checkmark$ & محدوديت هاى نقش \\
\hline$\cdot / k r$ & $\cdot / \mathrm{AV}$ & 9 & YN/q & ro & 11 & 9 & افسردگى \\
\hline$\cdot / 4 \Lambda$ & $\cdot / 9 r$ & $\Delta / \wedge$ & $r Y / 9$ & FF & ir & v & روابط با همسر \\
\hline ا וr/. & .190 & $f / f$ & r. & FF & if & 4 & انزواى اجتماعى \\
\hline • & $\cdot / \wedge \Delta$ & $F / 9$ & $1 F / \Delta$ & $r$. & If & 1. & رشد خود كنترلى \\
\hline$\cdot / r 1$ & .199 & $4 / 9$ & $1 / 4 \Delta$ & $r$. & ir & 1. & رشد تحصيلى \\
\hline$\cdot / 10$ & $\cdot / k$. & 9 & $1 / 91$ & $r$. & If & 1. & بهز يستى والدين \\
\hline$\cdot / r \mid$ & .194 & $\Delta$ & $1 Y / 9$ & $r$. & 10 & 1. & روابط خانو ادكى \\
\hline$\cdot / 49$ & $\cdot / \Delta \Lambda$ & $r G / r$ & $\mathrm{~V} / \mathrm{A})$ & $1 \wedge$. & v^ & 4. & شاخص رشد كل \\
\hline
\end{tabular}

در جدول زير دادههاى مربوط به همبستخى بين

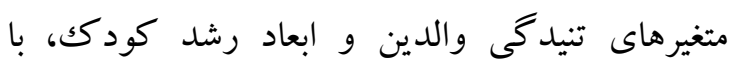
استفاده از ضريب همبستكى ارائهده است.
بررسى همبستخى بين ابعاد مختلف متغيرهاى تنيدگى والدين و ابعاد رشد كودك:

ضريب همبستكى ابزارى آمارى براى تعيين نوع و و ودرد درجه رابطه يك متغير كمى با متغير كمى ديخر است 
جدول r. همبستكى بين ابعاد مختلف متغيرهاى تنيد

\begin{tabular}{|c|c|c|c|c|c|c|c|}
\hline رشد كل & خانوادكى روابط & بهزيستى & تحصيلى رشد & خود كنترلى & اجتماعى رشد & هيجانى رشد & متغير ها \\
\hline$-\cdot / \Delta r^{* * * *}$ & $-\cdot / 1 / 44^{* * *}$ & $-\cdot / Y Y^{*}$ & $-\cdot / F Y^{* * * *}$ & $-\cdot 109^{* * *}$ & $-\cdot / \Delta r^{* * * *}$ & $-\cdot 104^{* * *}$ & بى توجهى / فزون كنشى \\
\hline$-\cdot / q^{* *}$ & $-\cdot / \mu Y^{*}$ & $-\cdot / r r^{*}$ & $-\cdot / r Y^{*}$ & $-\cdot / F f^{* * *}$ & $-\cdot / \mu q^{*}$ & $-\cdot / F F^{* * *}$ & تقويت گرى \\
\hline$-\cdot|F|^{* * * *}$ & $-\cdot / 4 \cdot * * *$ & $-\cdot / r \Delta^{*}$ & $-\cdot|F|^{* * * *}$ & $-\cdot / \Delta r^{* * *}$ & $-\cdot|F|^{* * * * *}$ & $-\cdot / \Delta \cdot{ }^{* * *}$ & خلق كودك \\
\hline$-\cdot / \notin 4^{* * * *}$ & $-\cdot / A r^{* * * * *}$ & $-\cdot /\left.\mu\right|^{* * * * *}$ & 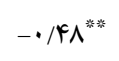 & $-\cdot / \Lambda^{* *}$ & $-\cdot|F|^{\text {絭 }}$ & $-\cdot / \Lambda^{*}$ & يذيرندگى \\
\hline$-\cdot / F D^{* * *}$ & $-\cdot /\left.\mu\right|^{*}$ & $-\cdot / r V^{*}$ & $-\cdot / r Q^{*}$ & $-\cdot / F Q^{* * * *}$ & $-\cdot / F D^{\text {***** }}$ & $-\cdot / F Y^{* * * *}$ & احساس صلاحيت \\
\hline$-\cdot / \Delta 4^{* * *}$ & $-\cdot /\left.\right|^{*}$ & $-\cdot / Y 4^{*}$ & $-\cdot / \mu Y^{*}$ & $-\cdot / \Delta \Lambda^{* * * *}$ & $-\cdot / \Delta r^{* * * * *}$ & $-\cdot 10 \Lambda^{* * * *}$ & دلبستگى والدين \\
\hline$-\cdot / \mu 4^{*}$ & $-\cdot / r 4^{* * * *}$ & $-\cdot / 1 \Lambda^{*}$ & $-\cdot / \Gamma \Delta^{* * * * *}$ & $-\cdot / \Delta 9^{* * *}$ & $-\cdot / q^{* *}$ & $-\cdot / \Delta r^{* * * *}$ & سازش بذيرى \\
\hline$-\cdot / \mu r^{*}$ & $-\cdot / \Gamma q^{* * * *}$ & $-\cdot / r \cdot *$ & $-\cdot|F|^{* * * *}$ & $-\cdot / \Delta 9^{* * *}$ & $-\cdot / \mu \cdot *$ & $-\cdot / 0 \cdot \cdot^{* * *}$ & فزون طلبى \\
\hline$-\cdot /\left.F\right|^{* * * *}$ & $-\cdot / F r^{* * * *}$ & $-\cdot / 19^{* *}$ & $-\cdot / \& 4^{* * * *}$ & $-\cdot / \Gamma q^{*}$ & $-\cdot / \notin q^{* * * *}$ & $-\cdot / \mu \Lambda^{*}$ & محدوديت هاى نقش \\
\hline$-\cdot / r V^{*}$ & $-\cdot /\left.\right|^{*}$ & $-\cdot /\left.r\right|^{* *}$ & $-\cdot / I^{*}$ & $-\cdot / F q^{* * *}$ & $-\cdot / r r^{*}$ & $-\cdot / F \Delta^{* * * * *}$ & افسردگى \\
\hline$-\cdot / F Y^{* * *}$ & $-\cdot / 4 \cdot * * *$ & $-\cdot / r \cdot *$ & $-\cdot / F Y^{* * * *}$ & $-\cdot / \Delta r^{* * * * *}$ & $-\cdot / F r^{* * * *}$ & $-\cdot / \Delta r^{* * * *}$ & روابط با همسر \\
\hline$-\cdot / Y \Lambda^{*}$ & $-\cdot /\left.F\right|^{* * * * * 2}$ & $-\cdot / \mu r^{* * * *}$ & $-\cdot|F|^{* * *}$ & $-\cdot / \Gamma q^{*}$ & $-\cdot / r 9^{*}$ & $-\cdot / \mu \varphi^{*}$ & انزواى اجتماعى \\
\hline$-\cdot /\left.4\right|^{* * *}$ & $-\cdot / r r^{* * * * *}$ & $-\cdot|r|^{* * *}$ & $-\cdot / \Gamma \Delta^{* * *}$ & $-\cdot / F r^{* * * *}$ & $-\cdot / q^{* * *}$ & $-\cdot / 4 \cdot \cdot^{* * *}$ & سلامت والدين \\
\hline$-\cdot / \Delta r^{* * * *}$ & $-\cdot|\mu|^{* * * *}$ & $-\cdot / Y Y^{*}$ & $-\cdot / / 4^{* * * * *}$ & $-\cdot 19 \Lambda^{* * *}$ & $-\cdot / F b^{* * *}$ & $-\cdot / q \Delta^{* * *}$ & اختيارى \\
\hline 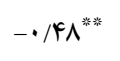 & $-\cdot / \mu V^{* * * *}$ & $-\cdot / r r^{* * * *}$ & $-\cdot / q^{* * * *}$ & $-\cdot / \Delta r^{* * * *}$ & $-\cdot / \uparrow 4^{* * *}$ & $-\cdot / \Delta r^{* * * *}$ & تنيدگى \\
\hline
\end{tabular}

حاضر موردبررسى قـرار گرفتـ و شـرايط لازم برقـرار بـود. شـرط بعـدى اسـتفاده از آزمهون تحليـل واريـانس

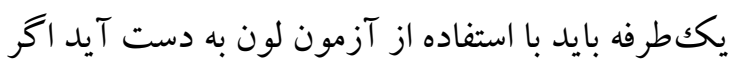

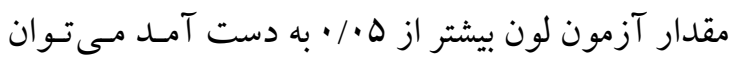

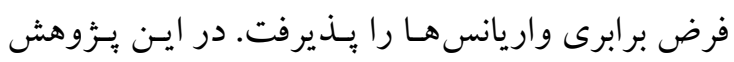
جون مقدار آزمون لون عدد ها / • محاسبهشـده و بيشتر از حد استاندارد هـ • • به دسـت آمـد از آزمهون تحليـل

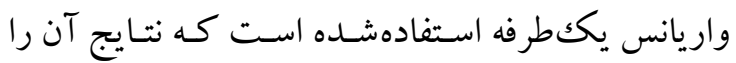
مىتوان در جداول بايين مشاهده كرد. با توجه به نتايج آزمون تحليل واريانس مى توان كفت كه مقدار F (19/94) براى متغيرهاى تنيدگى والدئ لدين معنى دار ( ( • • •) بهدست آمده است؛ بهعبارتديخر اين مقدار نشان مىدهد كه حداقل بين دو عامل تفاوت معنى دارى وجود دارد كه براى بررسى اين مدعا كه تفاوت كدام منطقه با كدام منطقه بيشتر است از مقايسات زوجى توكى استفاده شد و مشخص شد
در جدول بالا، همبستخى هر كدام از متغيرها با تنيدگى، در دو سطح معنىدارى كوجکكتر از يككهزارم و كوجّك تر از ينج صدم محاسبهشده است. لذا در سطح كوجّك تر از اين مقدار، روابط معنىدار هستند؛ بنابراين بين تمامى متغيرها، در سطح مذكور با تنيدگى ارتباط

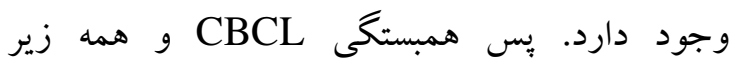
مقياس هاى آن با PSI معنى دار بود.

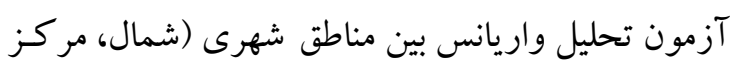

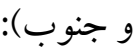
آزمون تحليل واريانس يككطرفه بـراى بررسى تفـاوت

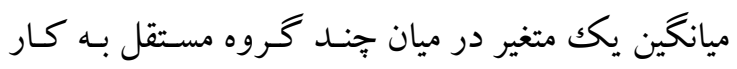

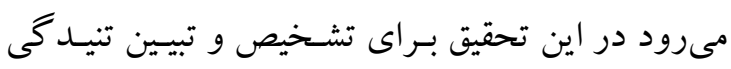

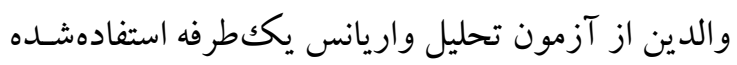

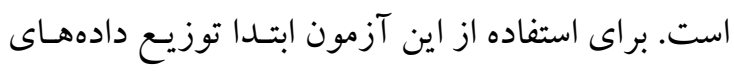

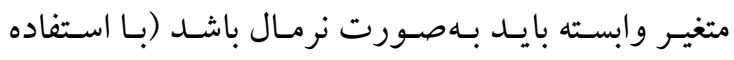

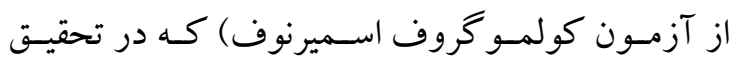


استفاده مى شود. مقدار آزمون KMO دست آمد كه نشان مى دهد وضعيت داده ها براى تحليل عاملى در حد خوب است. همجنين آماره بارتلت نيز در سطح درصد اطمينان 99, · معنى دار

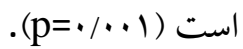

شاخص تنيدگى در شمال بالاتر و در جنوب بايينتر از ساير مناطق است (1 (•) (•). تحليل عاملى متغيرهاى تنيدگى والدين: از روش تحليل عاملى جهت بى بردن به متغيرهاى

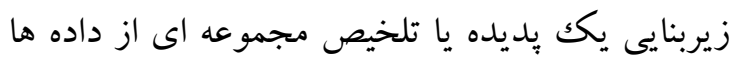

جدول r. عاملها و متغيرهاى تنيد

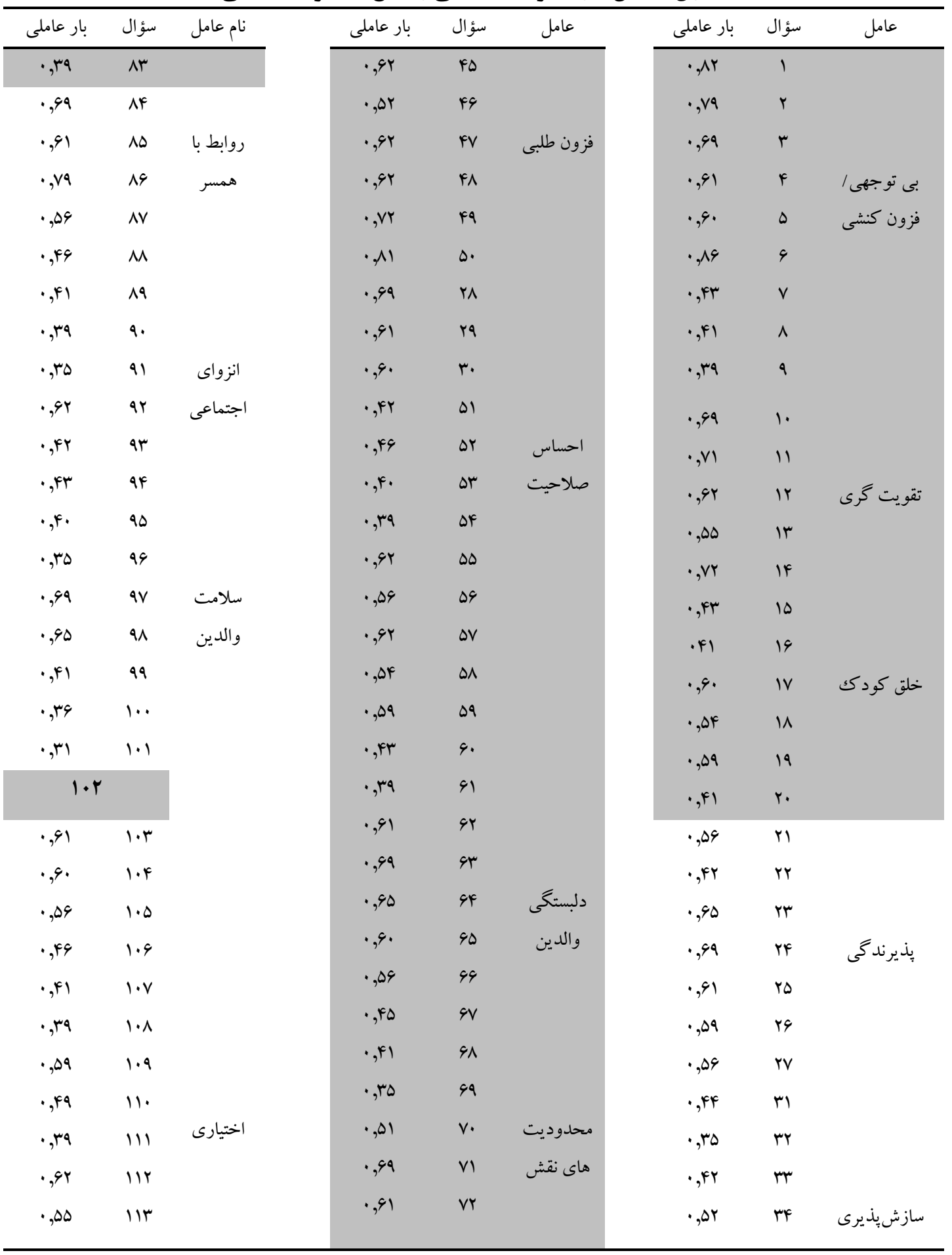




\begin{tabular}{|c|c|c|c|c|c|c|c|}
\hline$\cdot, \Delta q$ & $11 F$ & $\cdot, \Delta Q$ & $v r$ & & $\cdot, \Delta 9$ & ro & \\
\hline • & 110 & $\cdot, \Delta 9$ & $V^{F}$ & & $\cdot, 9 Y$ & rq & \\
\hline$\cdot,+4$ & 119 & & & & $\cdot, \Delta \cdot$ & rV & \\
\hline$\cdot, \Delta 9$ & $11 \mathrm{~V}$ & & & & $\cdot, \Delta q$ & r & \\
\hline$\cdot, 99$ & 111 & $\cdot, F F$ & VD & & & & \\
\hline • • & 119 & $\cdot,+4$ & Vq & & & & \\
\hline \multirow[t]{6}{*}{$\cdot, \uparrow \wedge$} & Ir. & • & W & & $\cdot,+4$ & rq & \\
\hline & & • • & $\mathrm{v \Lambda}$ & افسردحىى & • & $f$. & \\
\hline & & ·, $\Delta r$ & Vq & & • & FI & \\
\hline & & $\cdot$, Fr & $\wedge \cdot$ & & $\cdot$, FY & Fr & فزونطلبى \\
\hline & & $\cdot, 4 q$ & $\wedge 1$ & & $\cdot, 90$ & $\mathrm{Fr}$ & \\
\hline & & , & $\Lambda r$ & & r & FF & \\
\hline
\end{tabular}

در همين خصوص كار با والـدين و مــاخلات خـانو اده

محور مطمئناً نتايج كامل ترى را در بيى خواهد داشت ودين.

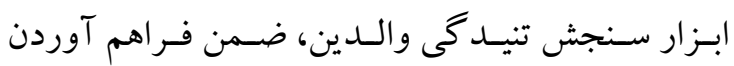
امكان خود سنجى براى والدين كود كان، مى تواند ابزار

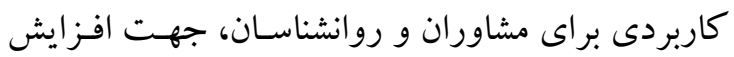

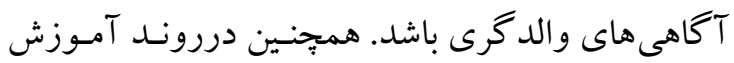
خانواده و تشخيص و درمان مشكلات عاطفى و رفتارى كود كان، بهصورت و غيرمستقيم، مى تـوان از ايسن ابـزار

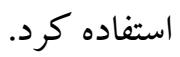

\section{References}

Abdin, R. R. (1990). Introduction to the speial issue: The stress of parenting. Joumal of clinical child psychology, 19, 298-301.

Abidin, R. R. (1983). Parenting stress index Manual. (3rd ed) University of Virginia.

Abidin, R. R. (1990). Parenting Stress Index manual (2nd ed.).Charlottesville, VA: Pediatric Psychology Press.

Ajilchi.B, BorjAli. A, Janbozorgi, M. (2011) The study of effectiveness of parental skills training on decreasing matemal stress, Joumal Quarterly Clinical Psychol Studies, Vol.4(1)

Baker, B. L. Heller, T. L. \& Henker, B. (2000). Expressed emotion, parenting stress, and adjustment in mothers of young children with behavior problems. The Journal of Child
بحث و نتيجل

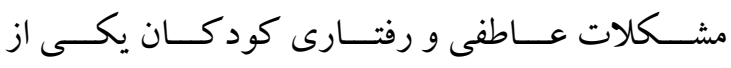

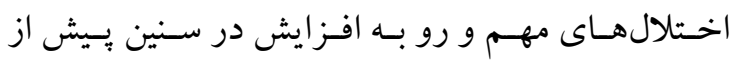
دبستان است كه نياز به توجه و صرف وقـت روزافزون از سوى متخصصين دارد و تا به امروز بـه ايـن خـروه از

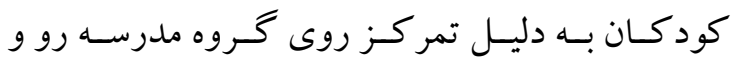

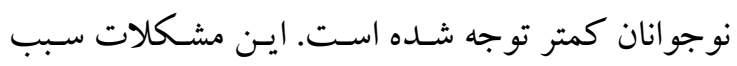
ايجاد رابطه معيوبى بين والدين و كود كان مسشـود كـه در صورت عدم مطالعه و تحقيـق و يـزوهش و صـدالبته مداخله بهصورت دوطرفه، هم براى كودكك و هم بـراى

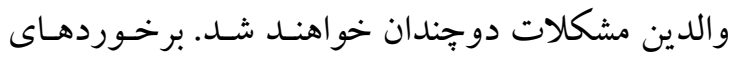
نادرست بين والدين و كودكك داراى مشكلات رفتـارى

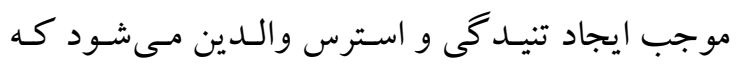

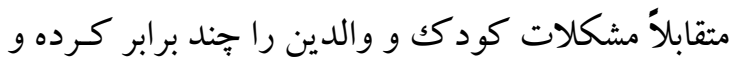

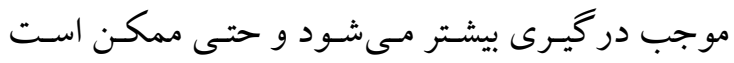
مداخلاتى كه با كودك اجرا مىشـوند نيز دجّار وقفـهـ

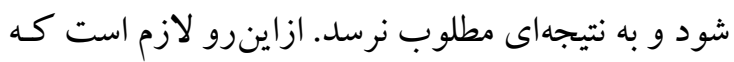

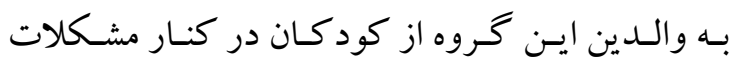
كود كان توجه شود و در جهت كاهش اين برخوردها و فشارهايى كه براى خانو اده به دنبـال دارد، تـلاش شـود.

Psychology and Psychiatry and Allied Disciplines, 41(7), 907-915. 
Barimani,S, Mahmudi, GH, Masoudzadem,A (2013) Gary Parent Stress Associated with Parenting Practices of Parents of Deaf and Normal Children, Volume 2, Issue 3, Autumn, Journal of health breeze, pp: 9-14

Dadsetan, P. Ahmadi Azghandi, A. Hassanabadi, H. (2006). Parenting stress and general health:a research on the relation between parenting stress and general health among housewife-mothers and nurse-mothers with young children. developmental psychologists, 2(7), 171-184

Farzad.V, Haidaali, H, Falah, F(2009)Psychological Characteristics of Parent Stress Test on Parents of Primary School Students, Psychological research, 2(2),PP:17-33

Farzadfard, S. Hooman, H. (2008). The role of child rearing training skills in reducing mothers stress and children,s behavioral problems. developmental psychologists, 4(15), 277-292.

Parand, A, Movallali, G (2011) The Effect of Teaching Stress Management on the Reduction of Psychological Problems of Families with Children suffering from Hearing-Impairment, Joumal of Family Research Vol.7(1);23-34

Rahimzadeh, S, Pooretemad, H, Sami-ei Karani, H, Ali Zadeh Mohammadi (2008) assessing the mental health of parents with ADHD Children and Suggesting the methods of intervention, Joumal of Iranian psychologists. Vol.4(16)

Reitman, D. Currier, R. O. \& Stickle, T. R. (2002). A critical evaluation of the Parenting Stress IndexShort Form (PSI-SF) in a Head Start population. Joumal of Clinical Child and Adolescent Psychology, 31(3), 384-392.

Saif, A, (2008) Behavior modification and behavior therapy, Tehran, Dawaran pub

Saloviita, T. Itälinna, M. \& Leinonen, E. (2003). Explaining the parental stress of fathers and mothers caring for a child with intellectual disability: A double $\mathrm{ABCX}$ model. Journal of Intellectual Disability Research, 47(45), 300-312.

Sarabi Jamab, M, Hasanadadi, A, Mashhadi,A, Asgharinekah,M (2012)The Effects of Parent Education and Skill Training Program on Stress of Mothers of Children with Autism, Joumal of Family Research Vol.8(3);261-272

SHahrakipour, H, Karim zadeh, S, keramaty, M(2009) The Impact of Family Life Education on Reducing Tension among Mothers with Learning Disorder Children in Reading and
Writing, Joumal Modern Thoughts In Education, Vol.3(47)

Shokoohi, Y, Zamani, N, Parand, A, Akbari Zardkhaneh, S(2011) The Effectiveness of anger management training of parents Anger Expression and control, Journal of Iranian psychologists. Vol.7(26)

Teimoor, S, ataeyfar,R(2000) Relationship between Parental Stress and Children's Affective, Clinical Psychology Andishe va raftar,16 (4). 